\title{
Intervention in markets of violence
}

\author{
Georg Elwert
}

\section{Introduction}

W ARLORDS DESTROY THE backbone of a state, the monopoly of violence. The society loses its cohesion. Behind smokescreens of ethnic, political, religious or other ideological goals appears a new - mainly economicreference for social action: acquisition based upon violence. Markets of violence are highly profitable social systems, which can remain stable over several decades. The dominant actors in this system, the warlords, combine violent appropriation with peaceful exchange.

Markets of violence generally originate in conflicts of a non-economic nature. The continuation of the violence is, however, based on economic motives or unconscious economic behaviour. From the perspective of the warlords, violence can be used to maximise profit to such an extent that it is on a par with other economic methods. The fact that the balance sheet is far from positive in its effect on the overall system is irrelevant. This inherently rational economic behaviour can continue as long as the warlords are able to exercise their power without the support of the majority.

The expansion in economic potential, the fall in arms prices, the widespread existence of command-state structures and a reluctance on the part of foreign powers to intervene in such situations enables the continuation or even increase in such markets of violence. They can collapse as a result of the monopolisation of violence, the exhaustion of inner resources or a blocking of access to external resources. Only then can peace gain stability, when formal and informal institutions of conflict regulation limit the use of violence.

\section{Markets of violence and policies of help and intervention ${ }^{1}$}

Osama Bin Laden, the ghost behind the terrorist attacks of 11 September 2001, came out of a market of violence. Sudan's and later Afghanistan's territories 
enabled his group to train and organise their troops. Their place was among the warlords; they were respected as partners. The markets of violence, which enabled them to develop their organisational network, were older. Paradoxically it was the violent environment which gave them the time they needed to find, by trial and error, more and more efficient modes of operation for their ideological enterprise. This enterprise, al-Qaeda, shares with other warlords the condition that the income, be it from smuggling/trade, from violence or from donations (which is dominant for al-Qaeda), has to reproduce the power apparatus.

To analyse only the warlords' ideologies leaves the structural conditions of their enterprises in the dark. The protagonists and their representatives cite venerable traditions of hate, revenge and religious-moral obligations as justification for their activities. The long-term basic patterns of these markets of violence are, however, based on rational, comprehensible economic behaviour. Emotions, such as hate and, above all, fear are instrumentalised in this context but are not structurally formative. Actors, who are active within both the internal markets for blackmail and receiving stolen goods and external markets for gold, weapons and drugs, appear to fulfil an organisational function. The leading actors - and not necessarily the fighters who in addition to pecuniary gain are also motivated by other purposes - are primarily characterised by a high sensitivity for the economic rationale of their enterprise. This does not exclude the fact that their personal motives and - in most cases - their propaganda is dominated by an ideological self-representation. The economic aspect is, however, behind the reproduction and self-stabilisation of markets of violence.

The origins of such violent conflicts can be explained by other factors. The disintegration of the monopoly of violence - more precisely: the monopoly of coercion - can be triggered by a series of various motives and situations. The longer the violence lasts, however, the stronger the compulsion to rely on economic imperatives (cf. Waldmann 1999). In many cases, the continuation of the violence can be explained only in terms of the existence of markets of violence.

During the 1980s, the 1990s, and at the beginning of the twenty-first century, markets of violence could and can be found in Afghanistan, Angola, Bosnia, Chad, Columbia, Congo/Zaire, Ethiopia, Lebanon, Liberia, Mozambique, Northern Burma, Northern Mali, Sierra Leone, Somalia, Sudan, Tajikistan, the Caucasus and the Central African Republic. ${ }^{2}$ Acquisitive behaviour similar in nature to the markets of violence also plays a role in some other violent situations. Terrorism or military fights in Northern Ireland, the Basque Country of Spain, the southern Philippines, in northern Sri Lanka and some other regions instrumentalise ideological motives to win some popular support but follow a clear economic strategy for its reproduction. The state's monopoly of coercion is severely damaged insofar as it cannot hinder the economic reproduction of parastate structures which finance violence. Although these situations are not (yet) the dominance of a market, a market of violence, over a (civic) society, they may 
well degenerate into it once the state loses its last protective capacity or once the military and police convert into warlordism.

The concept of 'monopoly of violence' (Gewaltmonopol, literally 'monopoly of coercion', Weber 1922) should be central to any reflection about alternatives to markets of violence. In a social structure governed by a monopoly of violence it is not everyone who can use violence. The occurrence of violence is very much restricted. This creates violence-free realms. As Norbert Elias (1978) has shown, such violence-free realms were essential for the development of European civilisation out of the Middle Ages. For a democracy, a monopoly of violence is a necessary condition; but it can also exist perfectly well in undemocratic structures. It may, for example, be a class monopoly of knights and kings. Violence-free realms are more stable if even the persons authorised to use violence are bridled by the law. If they can exert coercion - including violent coercion - only within the limits of legal regulations and legal procedures, then violence-free realms become realms of predictability. Under them, long-term investments in intellectual formation and the means of production also make sense for persons far from the centres of power. The lack of a monopoly of violence produces (under competitive conditions) spaces open to violence - violence fields. In these violence fields, people invest individually in the social and physical conditions of security in much higher proportions. Development, growth or productive innovation are not their preoccupations.

The general practice of state policy towards violence fields organised by markets of violence is that of non-perception masked by humanitarian intervention. Formally, the continuous existence of the states concerned is assumed. Diplomats of the former states transformed into markets of violence are paid by the country of residence or feed themselves through some smuggling. Noninterference is justified with the sovereignty of the country, which once existed. Sometimes neighbouring states let their armies or secret services profit from the situation in order to pursue economic goals, as in the cases of Afghanistan, Sierra Leone or Zaire/Congo. In most cases some western states directly or indirectly send (under the cover of refugee programmes) humanitarian aid, which contributes to the warlords' economies. The influence goes, however, in both directions. These open spaces of violence offer excellent breeding and selection conditions for the evolution of new forms of organised crime and organised terrorism, both of which may also affect peaceful industrial countries.

\section{Markets of violence as systemic process}

Markets of violence are understood as economic areas dominated by civil wars, warlords or robbery, in which a self-perpetuating system emerges and links nonviolent commodity markets with the violent acquisition of goods. Violent and non-violent trade become so entwined that the system-specific opportunities for 
profit give direction. A self-perpetuating economic system emerges beneath the surface of a moral world-view and power conflicts - and even in the absence of such attempts at legitimisation. This may be based on the fact that the economic motive of material profit dominates beneath the surface. It is also possible that irrespective of the conscious motives of the actors (such as freedom, honour or revenge), only those actors who pursue economically profitable strategies - irrespective of their intentions - will survive. Markets of violence can emerge in areas open to violence, i.e. where there is no monopoly of violence. ${ }^{3}$ The disintegration of a monopoly of violence is not generally caused by directly economic factors. In fact, it is mainly political and not economic motives that predominate in the initial phase.

Areas where there are no rules, which build channels for the use of violence, are open to violence. The unregulated violence may lead to the establishing of routines, it will not, however, result in the formulation of rules. Contracts between the warring parties can also be breached. Violence can even destroy the clientelist relations within a warring party and between warlords, their chiefs and mercenaries. The officer of a warlord may revolt against him or may betray him allying with his enemies. The possibility of murder for the sake of murder cannot be excluded in areas open to violence, even if such a murder would appear uneconomical to most actors.

Thus, to summarise, a market of violence is a field of activity which is mainly characterised by economic aims, in which both robbery and barter and the related activities of collection of ransoms, protection money, road tolls, etc. feature. Each actor has a number of basic options ranging from theft to trade.

The generals, princes, militia chiefs and party leaders who lead the troops in such conflicts are known in the research as 'warlords'. This term is used without any acknowledgement of its connotations with respect to the civil or criminal legal status of these persons. Warlords are understood as entrepreneurs who use deliberate violence as an efficient tool for achieving economic aims. These 'entrepreneurs' differ from normal entrepreneurs in that they also use violence-although not exclusively - as an instrument for the generation of revenue. This image of persons primarily acting on an entrepreneurial level is confirmed by the few academic reports emerging from the centres of such conflicts. In Ethiopia, the same circle of actors who once fought each other now cooperate as peaceful entrepreneurs (Zitelmann 1993). This view does not coincide with the stereotypes largely propagated in the media, which cite emotions and tradition by way of explanation. Unlike pub brawls, modern wars necessitate strategic planning and logistics. The killing cannot be sustained without cool and calculated planning for supplies of weapons, munitions, food and fuel. The planning of strategic action and military logistics requires a cool head and not the sustained evocation of emotion.

Owing to the fact that since the end of the Cold War, the big powers have lost interest in violent interventions in such situations and in the control of weapons 
sales, an important external factor is no longer present. ${ }^{4}$ In Russia the nomenklatura even lost interest in controlling the events in its marginal territory Chechnya in the period 1991-94; the wars of 1994 and later years were merely a means to generate symbolic capital within Russian politics (Zürcher 1998: 107,117 , see also Chapter 6 in this volume). Organised crime made use of the situation. Markets of violence will continue to emerge wherever there is a coincidence of areas open to violence, exploitable resources and corresponding markets. Where the external framework conditions remain unchanged (particularly the reluctance to intervene and control the traffic in arms), they are more likely to increase than decrease in number. Whether the intervention in Afghanistan after the terrorist attacks of 11 September 2001 will bring a new policy of internationally coordinated intervention to restore monopolies of violence globally is yet to be seen.

\section{Partial markets and developed strategies}

The theoretical perspective presented here is less concerned with revealing economic motives behind conflicts bearing ideological labels, or demonstrating the economic success of individuals in situations previously solely characterised by destruction than with demonstrating the systematic character which lies behind conflicts which otherwise appear to be chaotic in nature. ${ }^{5}$ Thus, the observable regular forms of economic behaviour in these areas are focused on first, followed by the external economic forms of stabilisation and, finally, how such markets of violence are formed. The manifold causes of the emergence of the markets of violence do not explain their durability; this lies in their systemic nature.

The players in this game are not only former entrepreneurs or criminals. They may also appear (and subjectively act) as security providers, government officials, politicians or religious leaders. This does not change the need for reproduction, although it may add further sources of income. ${ }^{6}$ If a foreign country intervenes - as Russia did in Abkhazia - it may lose money; this is different to the warlords' calculation. ${ }^{7}$ The troops financed by this outside support have, however, to avoid deficit, and this does not exclude economic behaviour equivalent to embezzling credit or fraudulent bankruptcy on behalf of the troop leaders. Commanders financed by neighbouring countries, such as Russia and the USA in Afghanistan, have noted this possibility.

The decision whether to steal or obtain certain goods through commercial transactions is basically always open in the markets of violence. The warlords need to win time so that they can make strategic decisions and keep their options open. Thus, the actors are confronted with a strategic triangle of violence, trade and time. The warlord makes calculated moves between these poles, carefully considering and optimising the cost/benefit relationship. Given that it is often not recognisable as such, this calculating rationality is explained below. 
It is not suggested that cultural values or emotions have no structurally formative role to play in the social process. In the markets described here, however, optimisation processes are based exclusively on economic imperatives. This does not, however, eliminate the possibility that emotions make a significant impact on the cost aspect of the individual instruments and thus influence the cost structure of the market. Theft and enslavement are particularly obvious in this context. ${ }^{8}$ Theft, however, is rarely for personal consumption. Anyone who hauls off refrigerators, video recorders and cars in Bosnia (or removes gold teeth) is not fulfilling a personal need but is reacting to the demands expressed by the receivers of such stolen goods.

The production of violence is also based on economic imperatives. The aim is to reduce the cost of the violence. Weapons, munitions and fuel are indispensable resources and it is not advisable for the warlords to save money by skimping on quality. It makes more sense to economise on the fighters' fees. Thus, 'marauding', i.e. systematic theft by soldiers, is an obvious form of the reproduction of working capacity. Indeed, a market actually develops for the marauding itself. In other words, it is possible to participate in organised robberies for a fee. In Yugoslavia, volunteer organisations made use of the support of 'weekend soldiers' who on Friday afternoons for a suitable fee and the loan of weapons were bussed to the front to return with their rich pickings on Sunday evening. That sadists who have paid their money are also allowed to seek their satisfaction is 'economic' in this sense.

Costs can be reduced by the well-meaning activities of foreigners too, food aid has also been used to supply troops (e.g. in Liberia). Research reports on refugee camps in Africa, describe how they have been converted into barracks full of troops awaiting deployment. ${ }^{9}$ A parallel development could be observed in the Afghan refugee camps in Pakistan, which gave birth to the violent movement of the Taliban (Rashid 2001). The intervention of international donors follows a pattern which is instrumental for building up the organisational structures of warring groups and which later provides infrastructures for warlords, as one might have been able to note back in the 1960s, when violence broke out in Congo (cf. Mummendey 1997). The refugee camps in Congo, then established under UN supervision, bore considerable responsibility for the recruitment of the militia which continues to exist in Congo/Zaire. The parties succeeded in creating their armies by terrorising their 'tribal brothers'. Such developments are favoured by the collusion of warlords with organisations active in the distribution of aid. They do not wish to jeopardise the flow of aid as a result of critical reports and the absence of monitoring of the conflict's dynamics (beyond the mere counting of victims and the needy).

Another way in which the warlords can reduce their overheads is by exploiting desire for social prestige. Young men can easily be won over as highly motivated 'volunteers' if involvement in dangerous acts (e.g. multiple robberies) 
means they will be finally considered 'real men', or if the exercise of violence is one of the conditions of an initiation ritual. In Georgia, the criminal underworld and militant political leaders make efficient use of the prestige rituals of young males (Koehler 2000, see also Chapter 7 in this volume). Threats and acts of limited violence are central symbols of a code which communicates prestige, status and power ambitions. The high level of common violence thus reached several times brought the country to the brink of a dominant market of violence. If a country turns into a market of violence the ensuing chances for income generation through violence then affects the prestige pattern. In Albania in 1997-98, young males engaged in violence as an honourable activity. This activity, in a situation where the monopoly of violence had broken down, generated a considerable income. The exhibition of this wealth and the chance to master the violence under their own order brought the young men a status which the seniority system that had existed until then could not provide for them (Schwandner-Sievers 1998: 75).

In the short term the promise of justice and freedom - or to be more precise, the hope of resolving latent conflicts or overturning despotic rule - can be sufficient to mobilise volunteers (i.e. unpaid actors) and this is particularly important in the initial phase of a market of violence.

The generation of fear is a particularly cost-effective form of mobilising troops. Propaganda is thus an important instrument of production in such conflicts. From an economic perspective, 'senseless violence' can find a meaning in this way. The fear of retaliation on the part of the victims leaves no option open but to join an army or support it for one's own protection. Fear of revenge stabilises the system. Fear of becoming a victim of violence oneself can also motivate to preventive attacks. These are generally not based on strategic planning, can escalate rapidly and end in the slaughter of neighbours with whom the attackers may previously have had close relationships. Reports from Rwanda and Bosnia demonstrate the importance of radio and television propaganda in this context (Bringa 1995; Neubert 1999). In Rwanda, the radio service, which was set up using development aid funding, was responsible for spreading and reinforcing the fear which ultimately provoked the bloodbath.

The main difference between markets of violence today and those in the nineteenth century lies in the way in which propaganda can electronically reach large populations more quickly and cheaply. It can thus convert the fear of people into mass panic or participation in military actions (which are economically profitable for a small minority) on a scale previously unknown. The automation of revenge and fear of revenge creates unanimity where multiple memberships (e.g. based on language or religion) would previously have left people neutral towards the militant actors. This new unanimity means that massacres can take place on a large scale; there is no need to omit individual houses during firing. The militarily meaningful friend-foe distinction can now be ideologically 
reformed and take the form of 'ethnic cleansing'. The fear of being declared an enemy and thus becoming a potential victim, or fear of revenge, motivates civilians to assume the role of unpaid 'cleansing agents'.

The most important resource for trade is goods, which are easy to transport. For this reason, trade in valuable objects is of disproportionate significance in the market of violence. Precious stones and precious metals assume particular importance as they enable the transfer of large values in a single movement. ${ }^{10}$ Drug trading, e.g. opium in Afghanistan (Goodhand 1999), and the weapons trade are not less lucrative. Wherever markets open to violence have developed, trade does not only centre on these valuable commodities but may even be attracted to the area, as could be observed in Tajikistan and the Balkans. Professional protection of the transport of goods by warlords and possibly even entrepôt trade (temporary storage in a 'safe' location) can be particularly attractive services for all kinds of illegal trading such as drugs and weapons smuggling. Smuggling routes move into these areas. This leads to consequential feedback processes. Afghanistan's market of violence fostered drug smuggling, which helped to finance violence in Central Asia. The collapse of state structures there, especially in Tajikistan, widened the opportunities for drug smuggling from Afghanistan and stable production structures for drugs could be built (Goodhand 1999). The Bosnian market of violence created relay structures for Kosovo-based organised crime. This, together with the great weapons sale in Albania in 1997, contributed to the abolishing of state structures in Kosovo (see also Chapter 5 in this volume).

The collection of protection money - also referred to as duties - and the taking of hostages have assumed major significance as an intermediary activity between trade and theft in markets of violence. The guarding of goods is today a particularly relevant phenomenon. The 'work' of the diamond and gold smugglers in contemporary Congo/Zaire, ${ }^{11}$ qat traders in Somalia, emerald smugglers in Columbia and last but not least the protectors of convoys carrying food aid in Sudan, Somalia, Liberia and Bosnia, have made this branch of commercial activity the warlords' most important source of income.

In some markets of violence there is a commodity sold which the buyers do not recognise as such: the sacrifice of human lives for the sake of ideology. Battles are fought in pursuit of an ideal and accompanied by detailed reporting. Lives on both sides of the divide are sacrificed for one product, which is of value to emigrants or foreigners interested in the fate of the world. 'The Free West', 'the Socialist World Revolution', 'the Honour of Our Nation', 'Saving our Islamic Faith' are the issues which appear to be at stake. Considerable resources are transferred into the market of violence from outside if the warlords pay special attention to this commodity through the establishing of a special troop which is trained in rhetoric and international communication. It was in this way that Jonas Savimbi succeeded in selling his battles in Angola as both a sacrifice for the 
Maoist socialist world revolution and then later for the defence of the free West against socialism, before turning his attention again to his main activity in Angola's and Zaire's diamond business.

The victims of these sacrifices do not need to be in the market of violence itself. Terrorist attacks steered from within the market but targeted at outside goals can be no less efficient if they receive sufficient publicity. The al-Qaeda of Osama Bin Laden and others managed to win an important share in this donation market. Their annual income is estimated at between US\$20 and 50 million. Whereas other violent ideological entrepreneurs are engaged in the market of mass 'charity' (such as the IRA in Northern Ireland), al-Qaeda lives off the market of wealthy organisations and individuals. Each trade has its own rules. Whereas conventional warlords have to seek a military superiority simultaneously with the continuous control of exploitable resources, an ideology entrepreneur such as al-Qaeda requires the protection of a military partnership and has to remind the public from time to time of its existence by spectacular acts. Competition in the donation market among organisations of the same type produces an outbidding in the visibility of symbolic action.

If warlords blend their organisation with the features of a charismatic social movement, they may gain social cohesion and ease compliance with their commands. This is especially important if warriors have to undertake tasks far away from their commanders. In such a movement's atmosphere the perception of hierarchy is covered by the sentiment of living in a community of equals, of 'brothers'. The great utopian goal and the words of the guru create subjective clarity where before there was the mist of an opaque and chaotic future. Thus the hardships of daily life and all the petty conflicts lose relevance before the sentiment of their alleviation. One is in the clouds, flying to higher goals. Bin Laden's al-Qaeda network obviously made use of charismaticism as a resource (Elwert 2001b).

It is possible to observe an accumulation not only in the means of violence and money but also in time options. Time options are created first and foremost by ensuring means of subsistence. Such guarantees can take the form of contracts for food supplies (including those from aid organisations) or the delivery of tributes from enslaved farming communities. Time options are also created through pacts with competitors or opponents. Finally, time is won through negotiations: it is possible to negotiate about non-aggression, the delivery of supplies or pacts without necessarily being primarily (or even 'secondarily') interested in the non-aggression, goods or pact in question. What is important is winning time. Mediators who fail to understand this part of the strategic game become unsure and nervous when local or national rulers hold them in threatening situations. Some internationally noted attempts at mediation ride on concealed propagandist juggling with violence or exchange of goods and also time. Is it better to rob someone, extort a contribution, exchange goods or block everything 
and play for time? One plays for time, allowing the non-aggression to be bought and then calling it taxation, duty or financing the peace process. Time-wasting can weaken or simply unnerve the other side, making military success easier to achieve.

\section{Stabilisation of markets of violence: 'civil war' as a long-term state}

In fields of violence, the areas open to violence, a deregulated market economy develops. Economic opportunities determine who cooperates and who attacks whom. It is not ethnic groups and clans who oppose each other in these civil wars but economic interests. Economic systems based on the use and generation of violence become established, systems which repeatedly erect smokescreens of political or religious legitimisation. They are happy to assume and replay culturalistic interpretations, because this gives their activity a higher moral value and hinders outside intervention from persons sharing the same political or religious orientation.

One consequence of violent situations is that the opportunities for income generation disperse into alternative economic sectors. Trade, industrial production, peaceful commercial activity and agriculture enter crisis and completely collapse when they become dependent on continuous external inputs. Wages and income in these sectors sink. Invested capital is devalued. In many cases, the only way that those dependent on wages, and the self-employed can survive is to become soldiers and/or marauders. Entrepreneurs are well advised to invest their liquid capital in the formation of a troop and the purchase of weapons. Thus, it is not surprising that Somalia's warlords were previously - in times of peace mainly involved in wholesale trading or as political entrepreneurs, but also as partners in development cooperation. The incipient market of violence makes the (relatively) higher wages and profit opportunities in the violent market sector absorb work force and capital. Warlordism thus becomes established simultaneously with the increasing pressure on alternative income sectors, which for the most part lose their opportunities for reproduction.

Autostabilisation also involves efforts in the symbolic-ideological sphere. Armed parades in front of the cameras of international television crews are as much a part of the successful propaganda methods used by this trade as the demonstrative brutality. The ideological self-presentation, which forces violence to the forefront, is intended to stabilise the position in the market of violence. It facilitates inter alia the sale of 'protection' and the influx of donations.

The selection of victims is based on highly complex calculations. Not everyone with possessions is subject to theft. The warlords also need trading partners, supporters and neutral powers. It is helpful to allow the violence to follow clear symbolically delineated lines to enable them to feel safe. Religion, urban or rural costume, regional accents, etc. are all suitable as the basis for distinction here. 
They give the impression of ethnic or religious confrontation. However, no trading partner or associate can be sure that they will not fall victim to the covetousness of yesterday's ally. Given the high risk of betrayal of leaders by troops, commanders try to revive proven patterns of authority. These efforts can lead to an 'innovation' which will then undermine the markets of violence. In order to win an easy loyalty, leaders may emphasise the belonging of their subjects, the so-called ethnic or religious 'identity'. This multi-faceted word (not really a precise concept) means in this context that distinctions gain in importance and that a traditional authority is invoked which should bind members of the defined we-group. This may create or recreate ethnonational units with an authority structure and some legitimacy, which produces rule compliance. This may not end but stabilise the violence within clearly defined boundaries (Schlee 1996, 2000; Elwert 2001c). The progression to classic war as well as to a ceasefire between commanders who are representative and capable of entering into an agreement are both possible outcomes.

The widespread hope that the majority of the population which is the victim of violence and impoverishment will rebel against the warlords can materialise only if a monopoly of violence is established from outside. This promise was the strong argument of the Taliban, when they won over other warlord organisations in Afghanistan. Their failure to keep control shows, however, some of the conditions for lasting peace. Free elections and, what is often neglected, the establishment of justice, of peaceful forms of conflict regulation and the circulation of free information can make the monopoly of violence a normality for the state's citizen. It is not in the interests of the warlords to allow this to happen as long as their trade remains profitable. If an end to the violence is actually achieved, a shift in values often occurs within the population, which now places a taboo on the willingness to engage in violence. Thus, whoever establishes a monopoly of violence - whether by democratic or non-democratic means - can be sure of a high degree of legitimacy.

\section{Markets of violence as a breeding ground for evolutionary processes}

Nothing is forbidden in the market of violence; there are no bridles on creativity; everything is conceivable in terms of what one can create and maintain by one's own (armed) power. The brutal selection by violence - violence that pays - offers an efficient test for new institutions and new forms of violence. Any organisation unable to secure by its deeds the means to reproduce weapons and to sustain fighters will lose and has to give up. In the selection process the most efficient organisations show up rapidly. Markets of violence enable a high-speed evolution - from dinosaur to modern predator in a decade. If the organisation exhibits different forms it may also survive in different environments.

The al-Qaeda, active from Afghanistan, successfully combines features of a 
formal organisation with a network structure and, most notably, the features of a charismatic movement. It has changed its targets over time - the Saudi Arabian government, the Soviets in Afghanistan and now the United States. In Uzbekistan's Ferghana valley they started as agitators for the Wahabbist version of Sunni Islam against the region's traditional Islamic rituals. Then, after clear failure, they opted for the vigilant role criticising the 'unislamic' behaviour of some state officials. The means of donation collection, of propaganda and of internal communication have changed constantly, adapting and innovating after each failure. The virtues of systemic differentiation were thus learned. Special staffs were devoted to organisation, fundraising and the technologies of murder. Some specialist services were bought, some troops were rented out. These contractual relations bridged ideological differences. In 1998 some 'Arabs from the Arab peninsula' - probably al-Qaeda - asked the Tamil Tigers if they wished to rent out a brigade of suicide assassins (Elwert 2001b). That this Sri Lankan terrorist group is rather hostile to its own Muslim minority and has an ideology which blends Hindu and Marxist elements, did not hinder the contact. It failed because of the financial terms of the contract, the nationalist limitation of the Tigers necessary for their troops' cohesion, or because of the perishable character of the goods offered.

Warlords learned rapidly how to manage their financial assets. The time of gold-hoarding generals is gone. They launder money at the best European, North American and Caribbean banks. They invest their money in trade and transport and have, as the Elam Liberation Tigers of Sri Lanka have, a special office for asset management. Ironically, the only surviving part of the warlord-ridden Liberian State is its New York-based office of ship registration, which is a useful institution for some warlords' transport business. Bank accounts are held in Liechtenstein, Cyprus, on island dependents of Great Britain and in Canada and the United States. The safety of financial systems protected by a rule of law are largely preferred to the institutions of 'rogue states'.

Given that markets of violencelargely destroy the internal institutional structure and production potential of a country, they are highly dependent on clients, suppliers, banks and other services outside of their area. It is easy to overlook the importance of the service sector. Markets of violence need external infrastructure. Somali warlords, for example, make extensive use of educational centres, special hospitals, banks, insurance companies, stock exchanges and commerce arbitration courts in other continents (North America and the Middle East).

Markets of violence do not develop and exist in a vacuum. They grow out of self-organising social systems, which by virtue of their nature depend on an exchange with their environment, and they continue this exchange in (evolving) forms. Exchange across the borders of its own system is, therefore, one of the vulnerabilities of markets of violence. Blockades, i.e. the prevention of this exchange, can destroy them from outside. ${ }^{12}$ 
In markets of violence organised crime targeting the population of other states finds positive growth conditions as long as it does not seek its victims among the impoverished population of the host country itself. Criminal entrepreneurs in this environment have, however, different working conditions from the classic mafia (cf. Krauthausen 1997). They lack the support of corrupt but so far-reliable state institutions. But they profit from a considerable freedom margin. Warlords, ideological terrorists and organised crime share the same evolution-enhancing environment. What future threats may come out of markets of violence cannot be predicted with precision. It can only be said that the evolution goes on at high speed.

\section{Prevention and the origins of markets of violence}

For the sake of prevention it is important to know how markets of violence come into being. A monopoly of violence does not, however, disintegrate suddenly. It is merely perceived suddenly - when it is too late. It crumbles with increasing speed as a result of contraventions which reveal the fragility of the system. The sustaining success of robbers or the obvious violence of despotic local power holders may lead to this perception. In most cases, however, the monopoly of violence disintegrates from within. That means state intervention contravenes the notion of a legitimate use of violence, which exists among the people. These violations legitimate counterviolence or an imitation of this arbitrary violence for a competing despotism. Despotism is a characteristic of the Command State, 'the brother of the command economy'. In this form of government the authority present has priority over laws, contracts and other written regulations (Elwert 2001a). Clientelism and corruption overrule formal laws and they marginalise regulations, which should provide for fair markets.

Conflict as such does not lead to violence. 'Conflict' in the meaning attributed to this concept in the social sciences is any incompatible divergence of interests. Most conflict is dealt with by institutional arrangements providing for arbitration or compromise. Violence is the system's default option. In some societies avoidance may also be a current option. If a higher level of interaction is needed, then avoidance favouring societies will turn more often to violence, since alternative institutional arrangements are weak (Elwert 2001d). Modern societies are characterised by an 'institutionalisation of conflict'. The more conflicts a society can deal with peacefully, the greater its capacity for social transformation. The lack of conflict processing capacity is a major weakness of the Command State.

Arbitration and the security of the legal system can prove too weak or unreliable when they are heavily challenged by economic development. Thus the idea of 'self-help', materialised as violent strife or feuding, appears as a means of achieving justice. This option becomes especially obvious when economic 
growth necessitates a higher institutional capacity for conflict resolution. This 'self-help' takes violent forms particularly in the vital area of land rights: the expulsion of sections of the population during and immediately after periods of economic growth in Nigeria, the Ivory Coast and Central Asia led to the emergence of temporary or permanent fields of violence. If there is a higher level of economic activity, then people engage in more potentially conflictual interaction. These require a greater processing capacity of the regulating institutions. If these institutions did not grow at the same pace as economic development, then failure is probable and the avoidance of interaction or violence are obvious options.

The temporal coincidence of democracy movements and the increase in internal state violence has led some observers to the conclusion that one is the cause of the other. In actual fact, however, both are a consequence of the end of the Cold War. Large powers and former colonial powers now enjoy less legitimisation for intervention when violence or a power shift occurs in their area of interest. They now allow local actors to prevail in situations, where they would previously have taken immediate action. This can give rise to a situation whereby free elections take place without the monopoly of violence being in the hands of the state. It is also possible that parliaments elected in this way have no de facto legislative authority, as the public servants do not feel bound by the laws. The Command State does then also exist in democratic forms. Willingness to compromise is weak when it is perceived as a loss of the prestige - vital for assuring credibility in the future. Violence is the better alternative to compromise as long as the gradual conflict (the more-or-less conflict) does not replace the alternative conflict (the either-or conflict) as dominant paradigm of conflict interpretation.

Liberation movements or a violent opposition, which merely aims to transfer the exercise of the monopoly of violence to other (i.e. their own) hands, actually create a second pole of violence. When violence comes from both sides, the monopoly of violence can quickly collapse and areas open to violence emerge. In the course of further development, the economic motives for the exercise of violence can become dominant in these fields of violence. That is not to deny that politically motivated wars of liberation exist. The transition to an economy of violence is, however, fluid. On the one hand, the guerrillas gain legitimacy from the violent state despotism, a despotism which serves the individual profit of the officials; on the other hand, however, the long-term financing of weapons supply necessitates that the war sustains itself from the war. Thus, ideologically motivated fighters become economically motivated warlords who continue to promulgate the old ideology for the sake of greater legitimacy.

In local societies, which are not subject to central state control, an economic or technological imbalance - e.g. a demand for scouting services to help robbers or gold-digging, or cheap and efficient weapons - can lead to failure in the internal control of violence. In the case of the Ugandan civil war, the Ik, who were pre- 
viously mainly active as hunter-gatherers, saw the opportunity to enrol as scouts (Turnbull 1972). This brought about the partial disintegration of the internal moral control and produced a famine among the old and the women and children they left behind. In the highland of New Guinea, feuds became war when automatic firearms became available and replaced spears, bows, axes and cudgels. In Somalia, some militias emerged from nomadic self-help units, which needed to obtain access to wells and food without state protection. They obtained their weapons from their trading partners in the cattle trade who were economically dependent on the cattle supplied by the nomads. The young people whounlike in the traditional clan system - controlled these weapons soon discovered that the taking of hostages, protection and blackmail are also profitable activities. These examples throw light on both the problem of international weapons trading and the necessity of a monopoly of violence guaranteed by a state governed by the rule of law. These two areas were not previously considered basic concerns of development-aid policy; however, they clearly exercise a significant influence on development processes.

The disintegration of the monopoly of violence is a necessary but insufficient condition for the emergence of markets of violence. The future warlords must be at least familiar with the rules of a market economy. This explains why, for example, in the Caucasus and Central Asia the warlords mainly originate from the circles of the former 'shadow' economy. Furthermore, weapons, munitions and fuel must be available at acceptable prices. The fall in the price of the weapons of war which can be observed in Africa since the early 1990s may have contributed to the spread of markets of violence there (Lock 1997). Finally, a certain level of disposable resources must also be available. Extreme poverty of the victims prevents the emergence of markets of violence in situations open to violence (e.g. in the mountain regions of Afghanistan and Tajikistan). A concentration of wealth and access to legally or illegally exploitable resources promotes the emergence of these markets (e.g. precious metals and stones have sustained the markets of violence in Congo/Zaire since the 1960s). Thus, even if the other parameters remain unfavourable, positive economic development can favour the development of markets of violence.

When areas open to violence and the market economy coincide, there may be positive interaction between them; i.e. the market interests are increasingly realised in areas open to violence. Thus, the self-stabilising system of the market of violence is generated.

\section{How it ended: historical experiences on the demise of markets of violence}

Markets of violence 'only' ever exist for a few decades. There are several factors, which lead to their eventual demise. Everything is permitted in the radical free market economy, including breach of promise. Thus, anything that can stabilise 
relationships of trust is particularly in demand. Associations based on religion, language, origins or (secret) associations are created. Efforts are made to mark out small areas of internal morality, areas in which violence is eliminated and trust established, within the radical free market, which permits all violence and breach of honour. The invention of an ethnic group or religious community is one way of doing this. In Somalia and Afghanistan, for example, the concept of religious community (umma) came to the foreground.

Such moral groupings can lead to underground transformations, which can elude observers focused on violence for a considerable time. At the beginning of the twentieth century, underground secret societies flourished in China, which was torn and divided by warlords. They included groups with high ethical claims (even one Christian lay mission succeeded in becoming established among some of the armed troops). One of the secret societies, which flourished in this underground was based on a particularly successful combination of charismatic obedience, the concept of peaceful Utopia and efficient military organisation: the Chinese Communist Party. Many observers deemed it not contemporary owing to its moral rigour. And yet this was the very characteristic which proved the key to its success.

The disintegration of a market of violence can, of course, also lead to the outbreak of a classic war situation as discussed above. This often has particularly unpleasant consequences for the populations involved. In the 'normal' market of violence, owing to the cost of the violence there are actually fewer victims than in classic wars (e.g. in many phases in the development of the war in Afghanistan). The warlord also sees death in terms of its financial cost. The deployment of 'cheaper' volunteer forces, which are mobilised through fear of the enemy (e.g. fear of the 'enemy' ethnic group) can, however, result in a drastic increase in the number of victims. When the violence is used to serve noneconomic aims (such as territorial rule of an ethnic group or the prestige of a nation), when ethnic cleansing becomes an aim along with theft and blackmail, the nature of the activity changes and the number of victims increases. Why should warlords resist the temptation to put themselves in the service of such a 'superior' object if the business continues to be profitable for them (as demonstrated in the Bosnian conflict)?

No market activity is purely based on motives of profit, subsistence and consumption. Market events cannot be consolidated without secondary motivation. ${ }^{13}$ Secondary motivations - such as efforts to create a new ethno-national community - can become primary motivations, which then establish a new reference. This was also the European experience: the capitalists of the mercenary armies of the Thirty Years War became both power-accumulating statesmen and peaceful entrepreneurs (Tilly 1985). Then, as today in Lebanon, the exhaustion of resources caused by the violence may have contributed to the establishing of relative peace. 
The transition from market of violence to other forms of violence, or to more peaceful states, can, therefore, be achieved through three developments: (a) the exhaustion of resources, especially through the imposition of external blockades, (b) internal shifts in orientation linked to a military imbalance in favour of the carriers of the new ideology and (c) the imposition of a monopoly of violence accompanied by the creation of conflict resolving institutions. An important and typical change in orientation is the establishing of institutions which promote trust, the long-term predictability of the regulations and in addition - like relations - the moralisation of behaviour, or - like a legal system - the regulation of conflict. The transition period is characterised by ambivalent activity. It is as though players of a game seated together at the same table interpret the moves differently. Players judged 'irrational' in terms of the majority can prevail if they manage to gain control over a scarce resource or synchronise their actions with the effects of an external blockade or the exhaustion of internal resources.

\section{Means for developing prognoses about the growth or demise of markets of violence}

Even before a violence-free space comes into being, it can be predicted whether or not warlords will dominate the game. A sound prognosis requires first that the (potential) warlords' ideological statements are not taken at face value but as nothing more than a means to win support and deter interference. Analyses have to be based on economic facts and on social patterns. Ten parameters have to be studied with priority.

\section{The patterns of violence}

That violence is patterned is an important finding of anthropological research. Violence exists in every society at least as a default option if no other means to pursue power interests are attainable. Violence in every society is contained by a normative arrangement which anthropology calls 'embedding' (Elwert 2002). This arrangement may vary in respect of the functioning or failure of institutions in respect of the changing demands put upon them. The patterns of violence with their historical variations have to be described.

\section{The institutions of conflict regulation}

The study of institutions of conflict regulation is necessary in order to assess their efficiency. How far are they capable of processing conflicts in a peaceful way? And to what extent do people feel unsatisfied and opt either for avoidance or for violent solutions? 
The actual status of the monopoly of violence

How far is the monopoly of violence respected? In which social and regional sectors does violence occur without the legitimisation of the formal rules?

\section{Self-violations of the legitimate monopoly of violence}

As formulated above, the violation of the legitimate monopoly of violence is the most common of all triggers for civil war.

\section{The development of autonomous sanction capacities}

A recent study on warmongers and mediators draws our attention to the establishment of autonomous sanction capacities within subgroups as a necessary condition for their transformation into collective violent actors (Eckert et al. 1999). Once these groups have established such an autonomous sanction capacity they are 'ripe' for civil strife. Whether they start attacking other groups or defend their own depends instead on the perceived balance of power.

\section{The degree of violence inducing disinformation}

As shown above, disinformation may motivate violence out of fear. Disinformation is especially helpful for endo-strategic mobilisation, that is, a mobilisation whereby would-be leaders declare the need to defend their group against assumed enemies.

\section{Mobilisable economic goods}

Mobilisable economic goods have to be assessed. The quantities of goods which may be stolen, the money which may be attracted by ransom taking, extortion or hostage taking, or that which may be gained through illegal trade has to be compared with the income sources within the formal and legal sector of market economy. The availability of such goods is a necessary but insufficient indicator of potential transformations into markets of violence.

\section{The potential of violent ideological entrepreneurs}

Violent political organisations, which mobilise along ideological lines, may have a high fund-raising capacity outside their country. If the size of the resource flow depends upon spectacular deeds, then terrorism is a likely option. 


\section{Labour power assessment}

The number and quality of persons who could be mobilised as volunteers, soldiers, mercenaries, as compared with the numbers of such persons in peacekeeping forces is another good indicator.

\section{Resource transfer opportunities}

Stolen goods have to be sold, ransoms have to be collected. Profits have to be stored, saved or reinvested. All this requires safe structures for money laundering, transfer and investment. The availability of such structures enhances the chances of warlords dominating the game.

\section{Political options to promote peace from the outside}

\section{'Fattening the booty': or the ambivalence of distributing aid}

Currently the most common form of intervention in conflicts is humanitarian aid. Doctors and nurses are dispatched to the war zones; food and clothing are distributed to the victims of violence; infrastructures get repaired; for logistic reasons refugees or people suffering from hunger get concentrated in camps. This measure is highly ambivalent, since recruiting troops is made easier rather than more difficult for the warlords (as demonstrated by the example of Rwandan refugees in Congo/Zaire or the Taliban's recruits from refugee camps in Pakistan). Decentralised supply concepts would be more suitable. ${ }^{14}$ Warlords use refugee camps not only to recruit but also to regenerate their troops. They may also invite in humanitarian organisations because they can sell them their services as protection forces against the risks generated by other warlords or by themselves. Warlords may as well scale down the violence as long as humanitarian forces distribute food and repair infrastructures, if the population has become too poor to be robbed. Once the 'booty is fattened' the cycle of war starts again. It is impossible to completely avoid aid supplies being diverted from the intended recipients as a result of blackmail, 'duties', payments for transportation, protection or theft. It would, however, be possible to avoid such supplies being used to benefit the warlords more than their victims through monitoring. The 'booty-fattening' effect can be avoided only if humanitarian action also implies the establishing of a monopoly of violence.

\section{Blockade}

It is possible seriously to jeopardise the economic interests of warlords through blockades. Smuggling, the investment of the proceeds of trade, theft, blackmail 
or hostage taking in safe third-party states, weapons and fuel supplies are all vulnerable to intervention. Such blockades are, however, difficult to implement. They may involve extensive manpower and technological resources on the borders of the war zones. They necessitate that the personnel who carry out the border policing are authorised to use weapons in the completion of their duties (unlike in the former Yugoslavia). Such blockades must also be implemented as blockades of services, particularly the movement and laundering of money. This is seen by some states as interference in their 'freedom of banking'.

\section{Armed peacekeeping and the need for support for institution building}

In some situations, the market of violence can come to an end only if the intrastate monopoly of violence is guaranteed by external powers for a limited period of time. This policing (and in the sociological sense non-military) task has four prerequisites.

First, the arms and logistics resources available to the intervening powers must be such that they can cope with actors who are potentially violent. Secondly, the use of sanctioned violence must be based on legal state regulations and enjoy institutional back-up and control. If soldiers can abuse their power, the intervening force will degenerate into another warlord. Thirdly, weapons control must be achieved. Fourthly, everyday conflicts must be resolved in peaceful procedures, if violence in the form of self-help 'for the achievement of rights' is not to flare up again; that means building institutions. The linking up with local concepts of justice and local institutions is unavoidable here if the aim is to lay the foundations for the endogenous development of the rule of law by native powers. These institutions may be both formal and informal, e.g. those organising illegal markets (cf. Zürcher and Koehler's Chapter 13 in this volume).

All this is based on an assumption of socio-cultural competence on the part of the intervening party. This is seldom in evidence in the cooperation with developing countries and is sorely missed in situations of violence.

\section{Building civil society at a grassroots level}

A monopoly of violence can be established only if violence-free interaction is made a matter of routine in daily life. This normalisation of peace requires changes in what one expects from neighbours and from unknown persons. These changes require four conditions.

First, power abuses by state officers, especially arbitrary violence, have to be controlled. Institutions of justice specialised in this field are a highly efficient tool for ensuring this function. Secondly, criminality has to be curbed. Thirdly, imagined threats, e.g. from witches or from infectious diseases brought by strangers, 
have to be dispelled by enlightening information. Finally, peaceful forms of conflict resolution have to be low-cost and quick.

\section{Forcing violent actors into moves towards peace}

In many examples of peacekeeping through external forces the (former) violent actors are still present. A study of the peacekeeping process in Bosnia shows both the failures and successes of such processes (Gosztonyi 2001). Violence can be effectively scaled down provided that there is a consistent system of positive and negative sanctions, of rewards and penalties. Starting from the status quo the relevant parties have to agree in a formal or informal contract on what will be considered an improvement or deterioration in the situation. Sanctions have to be administered consequentially and with a high degree of consistency and reliability in respect of the so defined 'goal corridor'. To achieve this, first of all the donors and intervening forces must be coordinated. If not, they will be played off against each other. Then they have to invest heavily in monitoring what is going on at the local level. Positive sanctions may include investments in welfare, infrastructure and productive assets. Subsidies and bribes should be avoided or at least reduced in the process. Among the negative sanctions is of course the removal of these social or personal benefits. But they must go further. One option may be targeted actions against a warlord's investments in other countries. The use of the mass media in the country itself or in countries whose public matters to the 'warlord-come-politician' can be an efficient tool, a sanction through negative reputation.

Coercive violence - especially the arrest of rule violators or armed intervention to secure the implementation of measures which were part of the contract - must not be excluded. The Bosnian case shows that once such an intervention was delayed, the violence level increased. The predictability of the sanctions and clarity in the agreements are the peacekeepers' virtues; fuzziness and lack of specific consequences for certain actions give them Achilles' heels. We have observed that in situations of unstable peace the risk of misunderstandings owing to delayed action or ambivalent symbols is above average.

\section{Economic opportunities as a means of socio-cultural transformation}

Given that states of war particularly reward the values of the warring parties, there is a particular danger that peace will be seen as only a temporary cease-fire. In areas open to violence, a prestige situation specific to violence often gets established which links the opportunity for young men to acquire honour and respect by acts of violence against third parties or revenging the infringement of honour'. This prestige is mostly bestowed by informal institutions. Age-specific organisations of young males play an important role. As long as these institutions 
exist and this prestige situation remains, a reserve army for possible civil war strategies continues to grow, even in peacetime. This is not the only possible outcome in such situations. It is also possible to open new paths to social recognition. The promotion of entrepreneurial ambition in peaceful forms can transform potentially destructive energies and provide both profit and prestige. ${ }^{15}$

As violence is a product of men's social organisation, so are markets of violence. There is thus a chance to undo them.

\section{NOTES}

1 This chapter draws on earlier publications of the author. Notes and references are restricted to arguments not yet contained in Elwert (1999). For this version the author has to thank especially Julia Eckert, Kristóf Gosztony, Ulrich Hiemenz, Jan Koehler, Dirk Kohnert, Thomas Zitelmann and Christoph Zürcher for support in the empirical research (especially Julia Eckert, Kristóf Gosztony, Dirk Kohnert, Jan Koehler, Thomas Zitelmann) and style (especially Ulrich Hiemenz, Christoph Zürcher).

2 It is important to note that in all of these countries or regions, areas exist or existed where the use of violence was not a regular occurrence.

3 This system can be described as a 'market' only in the descriptive sense of economic anthropology. In other words, the exchange under this system is based on the exchange value of the goods and unlike reciprocal systems, personal trust between economic partners is not required. The system described here, in which breach of contract, blackmail and theft are the rule, could not be described as a 'market' in the normative sense.

4 The different forms of violence were not, of course, interpreted as revolts against state attacks, robbery or markets of violence during the Cold War era but as the subversive violence of opponents.

5 For more detailed versions of the theory of markets of violence see Elwert $(1997,1999)$. The first formulations of the theory were presented at a plenary session of the German Sociological Convention in Düsseldorf in 1992 chaired by Gudrun Lachenmann (Elwert 1996), and a workshop at the World Congress of Sociology in Bielefeld in 1994 chaired by Amrita Rangasami. I have to thank both of them not only for the invitation but also for advice and the lively debate.

6 On security firms in Southern Africa, see Misser (1997a, 1997b), on bureaucracies in the Sudan, see Keen (1996).

7 Uganda, which in 2000 was able to balance its budget 'in spite' of the presence of Ugandan troops in the neighbouring Congo, shows that governments may also win.

8 For example, in Mozambique cf. Geffray (1992).

9 For example, in East Africa for troops from Somalia, Sudan and Ethiopia, cf. Allen (1996, 1999); Duffield (1997); Hancock (1997).

10 Diamonds, emeralds, gold, silver and minerals containing rare elements appear on the shopping list. For the diamonds in Sierra Leone example, see Grill (2001), and for emeralds in Columbia, see Krauthausen (1997).

11 Gold trading and protection or extortion of protection money for the gold trade was the speciality of the warlord Laurent Kabila who has been active for over thirty years and has now reached new honour in Zaire/Congo.

12 It is, however, difficult to find examples of successful blockades. Mozambique after the changes in South Africa, which previously provided the external infrastructure for violence, is perhaps such a case. 


\section{Intervention in markets of violence}

13 This can be seen in German society, for example, in the prestige awarded for academic work, which is a condition for advancement on the academic labour market.

14 Gerd Spittler developed such a decentralised concept for hunger intervention in the Sahara (Spittler 1988).

15 Thomas Zitelmann observed this in Ethiopia (cf. Zitelmann 1993; Eckert et al. 1999).

\section{REFERENCES}

Allen, T. (ed.) (1996), In Search of Cool Ground. War, Flight and Homecoming in Northeast Africa (Genf).

Allen, T. (1999), 'War, genocide and aid', in G. Elwert, S. Feuchtwang and D. Neubert (eds), Dynamics of Violence. Processes of Escalation and De-Escalation in Violent Group Conflicts (Berlin), 177-202.

Bringa, T. (1995), Being Muslim the Bosnian Way: Identity and Community in a Central Bosnian Village (Princeton).

Duffield, M. (1997), 'Ethnic war and international humanitarian intervention: a broad perspective', in D. Turton (ed.), War and Ethnicity (Rochester).

Eckert, J., G. Elwert, K. Gosztonyi and T. Zitelmann (1999), 'Konflikttreiber - Konfliktschlichter. Erste theoretische Erkenntnisse einer vergleichenden Untersuchung in Bosnien, Bombay und Oromiya Regional State (Äthiopien)', Sozialanthropologisches Arbeitspapier, 75 (Berlin).

Elias, N. (1978), Über den Prozeß der Zivilisation I + II, 5th edn (Frankfurt/M.).

Elwert, G. (1996), 'Afrikanische Pfade für Europas Zukunft? Gegenwärtige und zukünftige Entwicklungen europäischer Nationalismen/Percorsi africani per il futuro dell'Europa? Sviluppi attuali e futuri dei nazionalismi europei', Annalisi di Sociologia/ Soziologisches Jahrbuch, 12: I-II, 123-161.

Elwert, G. (1997), 'Gewaltmärkte. Beobachtungen zur Zweckrationalität der Gewalt', in T. von Trotha (ed.), Soziologie der Gewalt (Special Issue, No. 37 of the Kölner Zeitschrift für Soziologie und Sozialpsychologie).

Elwert, G. (1999), 'Markets of violence', in G. Elwert, S. Feuchtwang and D. Neubert (eds), Dynamics of Violence. Processes of Escalation and De-Escalation in Violent Group Conflicts (Berlin).

Elwert, G. (2001a), 'The Command State in Africa. State deficiency, clientelism and power-locked economies', in S. Wippel and I. Cornelssen (eds), Entwicklungspolitische Perspektiven im Kontext wachsender Komplexität, Forschungsberichte des BMZ, Band 128 (Bonn).

Elwert, G. (2001b), 'Rational und lernfähig - Wer die Attentäter des 11. September bekämpfen will, muss zunächst ihre Logik begreifen', Der Überblick, 3, i-vii.

Elwert, G. (2001c), 'Primordial emotions and the social construction of we-groups switching and other forgotten features', in G. Schlee (ed.), Imagined Differences: Hatred and the Construction of Identity (Münster).

Elwert, G. (2001d), 'Conflict, anthropological perspective', in P. Baltes and N. Smelser (eds), International Encyclopedia of the Social and Behavioral Sciences (Amsterdam).

Elwert, G. (2002), 'Sozialanthropologisch erklarte Gewalt', in W. Heitmayer (ed.), Internationales Handbuch der Gewaltforschung, in print.

Geffray, C. (1992), La cause des armes au Mozambique: anthropologie d'une guerre civile (Paris). 
Goodhand, J. (1999), 'From Holy War to Opium War? A case study of the opium economy in north-eastern Afghanistan', IDPM Working Paper, 5 (Manchester).

Gosztonyi, K. (2001), 'International intervention in the Bosnian War', dissertation (Berlin).

Grill, B. (2001), 'Die Chaosmächte Westafrikas', Die Zeit (27 July), 3.

Hancock, G. (1997 [1989]), Lords of Poverty. The Freewheeling Lifestyles, Power, Prestige and Corruption of the Multibillion Dollar Aid Business (London).

Keen, D. (1996), 'Ein sehr bürgerlicher Bürgerkrieg', Die Tageszeitung (7 February), $16-17$.

Koehler, J. (2000), Die Zeit der Jungs. Zur Organisation von Gewalt und der Austragung von Konflikten in Georgien (Münster).

Krauthausen, C. (1997), Moderne Gewalten. Organisierte Kriminalität in Kolumbien und Italien (Frankfurt/M.).

Lock, P. (1997), 'Armed conflicts and small arms proliferation', Policy Sciences, 30 117-132. Misser, F. (1997a), 'Mercenaries or security men?', New African (December), 14-16.

Misser, F. (1997b), 'The mercenary as corporate executive', African Business (December), 8-14.

Mummendey, D. (1997), Beyond the Reach of Reason. The Congo Story 1960-1965 (Bonn).

Neubert, D. (1999), 'Dynamics of escalating violence. The genocide in Rwanda', in G. Elwert, S. Feuchtwang and D. Neubert (eds), Dynamics of Violence. Processes of Escalation and De-Escalation in Violent Group Conflicts (Berlin).

Rashid, A. Taliban. The Story of Afghan Warlords (London).

Schlee, G. '(1996), Traditionelle Totenrituale. Islamisierung und der Islam als Feindbild', in E. Orywal, A. Rao and M. Bollig (eds), Krieg und Kampf. Die Gewalt in unseren Köpfen (Berlin).

Schlee, G. (2000), 'Identitätskontruktionen und Parteinahme: Überlegungen zur Konflikttheorie', Sociologus, 1, 64-89.

Schwandner-Sievers, S. (1998), 'Wer besitzt die "Lizenz zum Töten” in Albanien? Oder: Fragen zu Gruppensolidarität und Gewaltlegitimation in einer "anderen Modernisierung”, in J. Koehler and S. Heyer (eds), Anthropologie der Gewalt. Chancen und Grenzen der sozialwissenschaftichen Forschung (Berlin).

Spittler, G. 1988), Handeln in einer Hungerkrise. Tuaregnomaden und die große Dürre (Opladen).

Tilly, C. (1985), 'War making and state making as organized crime', in P. Evans, D. Rueschemeyer and T. Skocpol (eds), Bringing the State Back In (Cambridge).

Turnbull, C. (1972), The Mountain People (New York).

Waldmann, P. (1999), 'Societies in civil war', in G. Elwert, S. Feuchtwang and D. Neubert (eds), Dynamics of Violence. Processes of Escalation and De-Escalation in Violent Group Conflicts (Berlin).

Weber, M. (122), Wirtschaft und Gesellschaft (Tübingen).

Zitelmann, T. (1993), 'Violence, pouvoir symbolique et mode de représentation des Oromo', Politique Africaine, 50:3, 45-58.

Zürcher, C. (1998), 'Krieg und Frieden im Transformationsprozess: Tschetschenien', in J. Koehler and S. Heyer (eds), Anthropologie der Gewalt. Chancen und Grenzen der sozialwissenschaftlichen Forschung (Berlin). 